\title{
DISTRIBUTION AND ECOLOGY OF ALCHEMILLA SPECIES IN OSOGOVO MT. AND WEST BALKAN MT. IN BULGARIA
}

\author{
Anna GAVRILOVA ${ }^{1}$ \& Antonina VITKOVA ${ }^{1}$
}

\begin{abstract}
The present study aims to determine some common species of genus Alchemilla (Rosaceae) in Osogovo Mt. and West Balkan Mt. in Bulgaria. The ecological conditions in seven habitat types according to EUNIS with detected presence of Alchemilla species are compared. According to this classification, the habitats that were found belong to six general types: Transition mires and quaking bogs (D 2.3), Mountain hay meadows (E 2.3), Moist or wet eutrophic and mesotrophic grassland (E 3.4), Acid alpine and subalpine grassland (E 4.3), Subalpine moist or wet tall-herb and fern stands (E 5.5), Evergreen alpine and subalpine heath and scrub (F 2.2). Seven species were reported in the investigated regions: A. crinita Buser, A. erythropoda Juz., A. flabellata Buser, A. glabra Neygenf., A. glaucescens Wallr., A. monticola Opiz and A. viridiflora Rothm. In the paper are submitted some new reports for the presence of A. crinita, A. erythropoda and A. glabra in the investigated areas. Some preliminary results concerning the resources of the examined species are obtained.
\end{abstract}

Key words: Alchemilla spp., West Balkan Mountain, Osogovo Mountain, EUNIS, resources.

Izvleček

V raziskavi smo predstavili nekaj vrst rodu Alchemilla (Rosaceae) na gorovjih Osogovo in Zahodni Balkan (Stara Planina) v Bolgariji. Primerjali smo rastiščne razmere v sedmih habitatnih tipih po razvrstitvi EUNIS, $\mathrm{v}$ katerih smo ugotovili prisotnost vrst Alchemilla. Po tej razvrstitvi najdene habitate uvrščamo v šest glavnih tipov: prehodna barja (D 2.3), gorski gojeni travniki (E 2.3), mokrotni mezotrofni in eutrofni travniki ali pašniki (E 3.4), alpinska in subalpinska travišča na kisli podlagi (E 4.3), subalpinska in alpinska visoka steblikovja (E 5.5), arktično-alpinske in borealne resave (F 2.2). V raziskovanem območju smo našli sedem vrst: A. crinita Buser, A. erythropoda Juz., A. flabellata Buser, A. glabra Neygenf., A. glaucescens Wallr., A. monticola Opiz and $A$. viridiflora Rothm. V članku so prikazana nova nahajališča vrst $A$. crinita, $A$. erythropoda in $A$. glabra na raziskovanem območju. Prikazali smo tudi predhodne rezultate koristne uporabe proučevanih vrst rodu Alchemilla.

Ključne besede: Alchemilla spp., gorovje Zahodni Balkan, gorovje Osogovo, EUNIS, ekonomska uporaba naravnih virov.

\section{INTRODUGTION}

Genus Alchemilla in Bulgaria consists of 35 species according to Flora of PR Bulgaria, vol. 5 (Assenov 1973), 26 of these species are presented in Flora Europaea, Vol. 2 (Walters \& Pawlowski 1968), and in Atlas Flora Europaea (Kurtt et al. 2007) the number of the species given for the country is 36 .
The representatives of the genus are perennial herbaceous plants, most frequently with creeping rootage and erect to raised stems. The basal leaves have long petioles, brought together in a rosette, the outlines of the leaf lamina are orbicular to reniform, lobed to various extend. The flowers have a doubled calyx, corolla-absented, brought together in botryoid inflorescences. The species reproduce by seeds through facultative

${ }^{1}$ Department of "Applied botany", Institute of Botany - BAS, Georgi Bonchev Str. 23, 1113 Sofia, Bulgaria, any_gavrilova@abv.bg 
apomixes, though hybridization does occasionally take place (Glazunova 1987, Izmailow 1994) and also vegetative, forming clone-populations. Some authors consider the species within the group to be a microspecies with wide genetic polymorphism (Sepp et al. 2000).

The Alchemilla species are poorly studied in the Bulgarian flora from the taxonomical and chorological aspect, as well as regarding their biological characteristics. In the Herbaria of the Institute of Botany-BAS (SOM) and the Biological faculty of Sofia University "St. Kliment Ohridski" (SO) there is an insufficient number of specimens, as the localities of some species remain not vouched for over the last 3-4 decades. Because of the highly valued medicinal properties of the larger part of the Alchemilla species, their resources are intensely exploited for personal needs as well as in the pharmaceutical industry. According to the Bulgarian legislation Alchemilla spp. are placed under special regime for harvesting with annual quotas (Medicinal Plants Act 2000). The sustainable utilization of the Alchemilla resources appears to be a problematic issue in Bulgaria because of the lack of scientific data on economically valued localities.

The present study is part of a larger one, regarding the perspective from the economic point of view of the Alchemilla species in Bulgaria. The aim is to determine the species diversity within genus Alchemilla and its relation with the habitat types in the investigated regions, which may prove useful for the sustainable utilization and preservation of the resources. The determination of the habitat types, combined with the respective species abundance, can become essential for the selection of plots for commercial exploitation. This approach closely relates to the sustainable use and preservation of the resources of Alchemilla spp.

\section{STUDY AREA}

The present study was conducted on the territory of Osogovo Mt. (without the north-western slopes) and part of the territory of West Balkan Mt. in the section of Varshetc town - Todorini kukli peak - Petrohan pass. The investigated regions were situated in West Bulgaria: Osogovo Mt. in south-western Bulgaria, and West Balkan Mt. in north-western Bulgaria.

According to the literature there is a certain resemblance in the geomorphologic structure in both investigated regions - West Balkan Mt. and Osogovo Mt. The mountain slopes are comparatively steep and have on the ridges well differentiated denudation plates. However, West Balkan Mt. has more highly varied relief than Osogovo Mt., because of the numerous river valleys and watershed hills of second and upper order (Vaptzarov et al. 1989, Penchev et al. 1989).

Both mountains come under different climatic regions - West Balkan Mt. under the temperate continental zone and Osogovo Mt. under the transitional continental zone; however, they have some similarities in with regard to climate. This is conditioned by the similar elevation range investigated in both mountains, and by the fact that Balkan Mt. and the mountains of the Macedono-Thracian Massif (with Osogovo Mt. as a part) gather the precipitations respectively from north-west and south-east enterings of moist air currents. However the winter on Osogovo Mt. is milder than the one on West Balkan Mt., and the humidity at a same elevation is lower as well in this comparison (Velev 2002). The water flow of the rivers in both mountains has a temperate continental influence and considerable snow melting supply, although Osogovo Mt. is perceptibly dryer in comparison with West Balkan Mt. (Jordanova 2002).

Regarding the soil type, the two regions belong to different soil sub-regions; however, at the same elevation, in both mountains brown mountain-forest soils prevail, well drained and damp due to the clayey-sandy structure (Ninov 2002).

\section{METHODS}

The analyzed data were obtained through the period 30.05.2008-14.08.2008. The investigations in the two mountain regions included a similar altitude range: for Osogovo Mt. from 1459 to $1791 \mathrm{~m}$ a.s.l., and for West Balkan Mt. from 1382 to $1711 \mathrm{~m}$ a.s.l. The species status was determined according to Flora of R Bulgaria (vol. I-X), Guidebook of vascular plants in Bulgaria (Kodzuharov 1992), and Guidebook of higher plants in Bulgaria (Delipavlov \& Cheschmedziev 2003). The data about the species distribution in phytogeographical regions is in conformity with Conspectus of the Bulgarian Vascular Flora (Assjov \& Petrova 2006), the available herbarium specimens in the Herbaria from the Institute of Botany (SOM) and Biological Faculty of Sofia University "St. 
Kliment Ohridski" (SO), and were synchronized with the latest development of genus Alchemilla in Atlas Florae Europaeae (Kurtto et al. 2007).

For the data collection the track method was applied. The experimental plots suitable for population investigations were chosen according to the natural ecological prerequisites of the Alchemilla species. These requirements excluded the forest massifs for their unfavorable light regime regarding the investigated species, as well as the herbaceous communities located under $1200 \mathrm{~m}$ a.s.l. for their most often xerophyle characteristics. The list of the floristic composition of the communities with presence of Alchemilla species was made with the support of quantitative estimations following the Braun-Blanquet method (1964) (Table 1), GPS locations and data on the elevation, inclination, exposition and humidity in certain localities were also collected. The set size of the experimental plots was at an average of $100 \mathrm{~m}^{2}$. The determination of the habitat types was completed on the basis of EUNIS (European Nature Information System) habitat classification (http://eunis.eea.europa.eu/habitats.jsp). The average area of the populations was estimated in decares (da), and the joint project coverage of the Alchemilla species for every locality was given in percents.

In the Herbarium of the Institute of Botany, BAS (SOM) were deposed specimens from the investigated regions for the new and confirmed species.

\section{RESULTS AND DISCUSSION}

\subsection{Floristic RESULTS}

Altogether, 191 species belonging to 40 families and 121 genera were found in the surveyed plot areas from both mountains.

As a result of the conducted study, seven species of genus Alchemilla L. were reported on the territory of the investigated regions of Osogovo Mt. and West Balkan Mt. (Table 1). Six of these species are common for both mountains: $A$. crinita Buser, A. erythropoda Juz., A. flabellata Buser, A. glabra Neygenf., $A$. glaucescens Wallr. and $A$. monticola Opiz. They are part of Sect. Alchemilla (Brevicaulon Rothm.) of genus Alchemilla, Subsect. Heliodrozium Rothm. From Subsect. Calycanthum Rothm. of the same section only one species is reported: A. viridiflora Rothm. from
Osogovo Mt., where it is known to occur (Assyov \& Petrova 2006).

In the present study A. crinita was submitted for the first time for the territory of Osogovo Mt. and West Balkan Mt. This species partakes in all floristic descriptions from Osogovo Mt., the major part of those being from West Balkan Mt.

A. erythropoda was reported for the first time for Osogovo Mt. and was confirmed its presence for West Balkan Mt., where herbarium specimens have not been collected since 1949. It was also the first report for the presence of $A$. glabra for West Balkan Mt.

\subsection{Distribution ANALYSIS}

All the localities found in both mountains are situated in the range of beech belt, out of the forest canopy or in the subalpine belt. The specified Alchemilla species occur in mesophile herbaceous, wetland and ericoid communities. These plant communities are distinguished by not more than 3 herbaceous sublevels (the third one lies directly on the ground, and where it is presented consists mainly of mosses) and also perennial herbaceous species (usually grasses) or small ericoid species (e.g. Vaccinium spp.) as dominant biological types.

As a result, from the comparison of the phytogeographic elements characterizing the species diversity in the investigated regions (Table 1, Figure 4), it is clear that in both regions there predominate European (Eur), boreal (Boreal), EuroAsian (Eur-As) and sub-boreal (subBoreal) floristic elements. Figuratively, these elements amount to $53 \%$ of all elements presented in Osogovo Mt., and $62 \%$ for West Balkan Mt. The distribution by life forms and biological types shows that all the described localities are dominated by perennial species (Figure 1) belonging to the group of hemicryptophytes (Figure 2) and are characteristic for territories with a moderate to cool climate. From the analysis regarding the humidity, it follows that in the investigated regions of both mountains the group of species bonded to more or less humid habitats (xeromeso-, meso-, mesohygro-, hygromeso- and hygrophytes) exceeds $70 \%$ (Figure 3). All these results show that in both regions the climate is distinguished by higher humidity and lower average temperatures. It is likely that this circumstance in some degree counter-balances the difference between the moderate- 

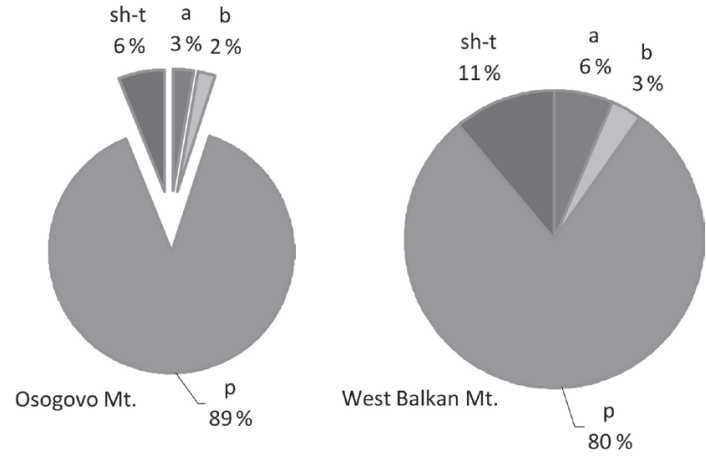

Figure 1: Distribution of the biological types in the investigated regions of Osogovo Mt. and West Balkan Mt. (a - annual; b - biennial; p - perennial; sh - shrub; $\mathrm{t}$ - tree).

Slika 1: Razporeditev bioloških tipov na gorovju Osogovo in Stara Planina ( $\mathrm{a}$ - enoletnice; $\mathrm{b}$ - dvoletnice; $\mathrm{p}$ - trajnice; sh - grm; t - drevo).
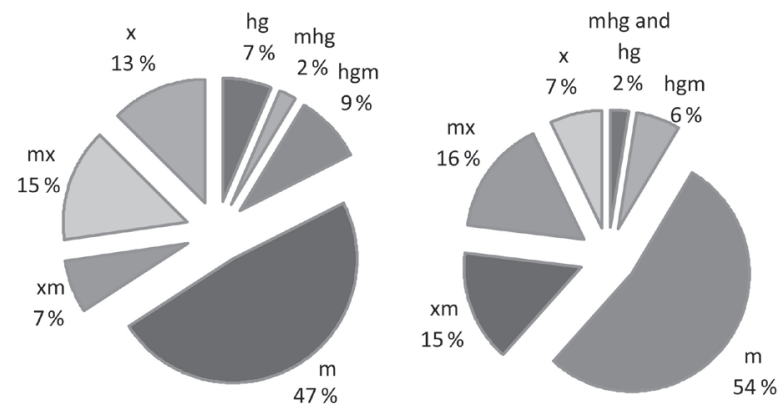

Osogovo Mt.

West Balkan Mt.

Figure 3: Distribution of the ecological types in relation to humidity in the investigated regions of Osogovo Mt. and West Balkan Mt. ( $\mathrm{m}$ - mesophytes; xm - xeromesophytes; $\mathrm{mx}$ - mesoxerophytes; $\mathrm{x}$ - xerophytes; mhg - mesohygrophytes; hgm - hygromesophytes; hg - hygrophytes).

Slika 3: Razporeditev ekoloških tipov v odvisnosti od vlažnosti na gorovju Osogovo in Stara Planina ( $\mathrm{m}-\mathrm{me}$ zofiti; xm - kseromezofiti; mx - mezokserofiti; $\mathrm{x}$ - kserofiti; mhg - mezohigrofiti; hgm - higromezofiti; hg - higrofiti).

continental (West Balkan Mt.) and transitionalcontinental climate (Osogovo Mt.), which influence the investigated regions respectively. These conditions offer a favorable environment to the Alchemilla species, which are naturally distributed in the mountain and high-mountain zone of Central and East Europe as well as in some other regions with similar features (Fröhner 1995).

Secondly are presented sub-Mediterranean
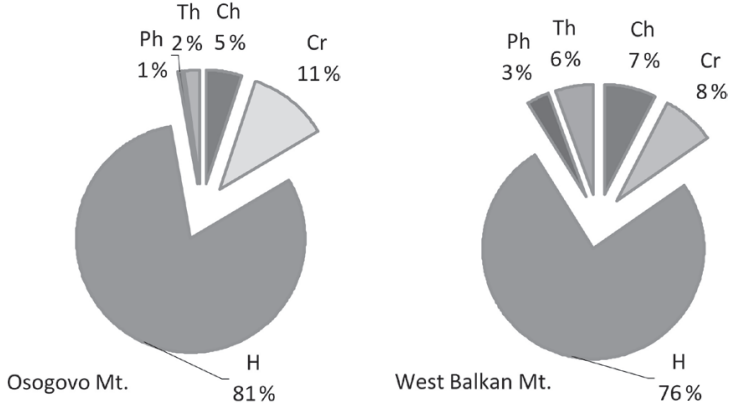

Figure 2: Distribution of the life form types in the investigated regions of Osogovo Mt. and West Balkan Mt. (Raunkiaer, 1937) ( $\mathrm{Ph}$ - phanerophytes; $\mathrm{Ch}$ - chamephytes; $\mathrm{H}$ - hemicryptophytes; Cr - criptophytes; Th - therophytes). Slika 2: Razporeditev življenskih oblik na gorovju Osogovo in Stara Planina (Raunkiaer 1937) (Ph - fanerofiti; Ch hamefiti; $\mathrm{H}$ - hemikriptofiti; $\mathrm{Cr}$ - kriptofiti; Th - terofiti).

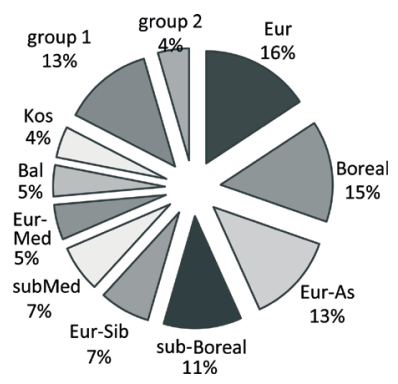

Osogovo Mt.

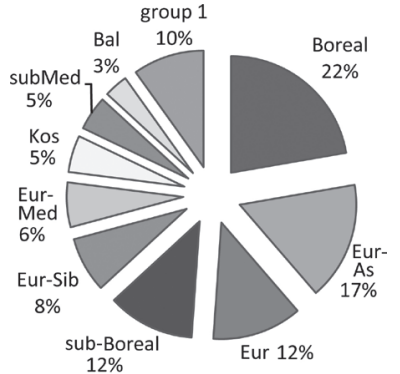

West Balkan Mt.
Figure 4: Distribution of the phytogeographic elements in the investigated regions of Osogovo Mt. and West Balkan Mt. (Osogovo Mt.: group 1 - Pont-Med; Arct-Alp; CarpBal; Med; Eur-subMed; sMed-Cas, group 2 - other phytogeographic elements. West Balkan Mt.: group 1 - Pont-Med; Arct-Alp; Eur-subMed; Carp-Bal, Alp-Carp-Bal and other phytogeographic elements).

Slika 4: Razporeditev fitogeografskih elementov na gorovju Osogovo in Stara Planina (Osogovo: skupina 1 - Pont-Med; Arct-Alp; Carp-Bal; Med; Eur-subMed; sMed-Cas, skupina 2 - ostali fitogeografski elementi; Stara Planina: skupina 1 Pont-Med; Arct-Alp; Eur-subMed; Carp-Bal, Alp-Carp-Bal in ostali fitogeografski elementi).

(subMed), Euro-Mediterranean (Eur-Med), Euro-Siberian (Eur-Sib), cosmopolite (Kos) and Balkan (Bal) floristic elements, which are smaller in number, and consequently do not characterize sufficiently the floristic diversity in the investigated regions.

Except for A. erythropoda, which is of limited distribution in South-East Europe (Assenov 1973), the remaining five species, common to 
both surveyed regions, have European (A. crinita, A. glaucescens), euro-Siberian (A. glabra, A. monticola) and Alpic-Carpathian origin (A. flabellata) (Assyov \& Petrova 2006). The main part of the populations of these species is distributed in the middle and high mountain belt of the Alps and Carpathians, and clearly forms two possible corridors for irradiation and genetic material exchange - one corridor follows the line that connects the Alpo-Carpathian range with Balkan Mt. (in particular West Balkan Mt.) as a natural continuation, and the second corridor stretches from the Central massif of the Alps, to the Dinaric Alps and then through the Serbo-Macedonian Massif to Osogovo Mt., which is the last formation of this massif to the east (Kurtto et al. 2007, Zagorchev 2007). The existence of these two possible corridors for irradiation may explain the exact correspondence in the Alchemilla species diversity, reported for the investigated regions of West Balkan Mt. and Osogovo Mt.

Regarding the similar ecological prerequisites of the six species common to both regions, one likely explanation of this fact is that they have very close taxonomic relations: all of them are positioned in Section Alchemilla, subsection Heliodrosium in two consequent series (series Pubescentes - A. glaucescens, A. flabellate, A. erythropoda; series Vulgares - A. monticola, A. crinita, A. glabra) of the genus (Walters \& Pawlowski 1968). Some authors express the opinion that, in the past, one way of species formation in the genus could be a result of hybridization in combination with introgression, which is common for apomicts groups like Hieracium, Rubus, Taraxacum or Ranunculus auricomus complex (Gehrke et al. 2008). This specific kind of species formation allows the descendent new species to share common ecological niches with their parent species, and their area remains sympatric. If we accept this assumption, it gives a reasonable explanation of the similar preferences of the closely related Alchemilla species in the borders of the described habitat types.

When comparing the descriptions of the separate phytocoenoses from the summarized habitats, one is impressed by the various number of $A l$ chemilla species forming different combinations. This could be explained by the fortuity in the dissemination of the seeds in combination with the possible transference of seeds from adjacent areas with similar ecological conditions. A good example of this is the presence of A. glaucescens in the habitat of Balkanic quaking bogs (D 2.3I) in Osogovo Mt. and the mountain hay meadows (E 2.33) from West Balkan Mt. This species is known from the literature to have xeromesophyle to xerophyle characteristics and it appears at considerably drier places (Lovelius 1987). Because of the specific characteristics of the bogs in Osogovo Mt., as a large number of localities compared with very small areas, we can assume that the species penetrated from the nearby acidophylous herbaceous communities for which it is typical. It should be mentioned that, in spite of the presence of $A$. glaucescens in the habitat of Balkan quaking bogs, it takes the peripheral niches of the habitat in the spatial and ecological aspect. Different is the situation with the occurrence of $A$. glaucescens in the Balkan mountain hay meadows from West Balkan Mt. Most likely this species had irradiated from the higher distributed opened acidophilous grasslands. It penetrates the hinder area of the forest belt, with its seeds probably transported along the springs or gullies, and with the water flow most often as a result of the melting snow.

With the regard to the habitat types where the reported Alchemilla species (A. crinita, A. erythropoda, A. flabellata, A. glabra, A. glaucescens and A. monticola) were found, we consider them from the perspective of characterization of their preferred environmental conditions as a projection of their habitats. For the territory of Osogovo Mt. the reported Alchemilla species are located in three main types of habitats: E 2.33 Balkan mountain hay meadows, E 4.318 Oro-Moesian mat-grass swards, and D 2.3I Balkanic quaking bogs. With biggest species diversity for genus Alchemilla are highlighted the habitat types of Oro-Moesian mat-grass swards (A. crinita, A. erythropodoides, A. flabellata, A. monticola) and Balkanic quaking bogs (A. crinita, A. erythropodoides, A. glabra, A. glaucescens) (Table 2).

For West Balkan Mt. the reported Alchemilla species occur in six types of habitats:E 2.33 Balkan mountain hay meadows, E 3.46 Continental humid meadows, E 4. 318 Oro-Moesian mat-grass swards, E 4.3944 Oro-Moesian [Sesleria comosa] grasslands, E 5.572 Moesian scarlet avens tall herb communities, and F 2.2A2 Balkano-Hellenic dwarf bilberry heaths. The biggest species diversity of Alchemilla representatives here is found in the communities with dominance of Vaccinium myrtillus and Vaccinium vitis-idaea (F 2.2A2 - A. erythropoda, A. flabellata, A. glabra, A. glaucescens), and in second place come the subalpine acidophilous herbaceous communities of type E 4.3944 
(A. erythropoda, A. glabra, A. glaucescens) and hay meadows (E 2.33 - A. crinita, A. glaucescens, A. monticola) (Table 3$)$.

The bigger number of habitats for West Balkan Mt. compared with Osogovo Mt., where $A l$ chemilla species were found, can be explained by the more varied relief as a result to the large number of river valleys and feeders of different order.

The habitat type of E 4.394 Oro-Moesian aeolian grasslands is ascertained for the wide area near Ruen peak in Osogovo Mt., and there are sparsely presented $A$. glaucescens and A. erythropoda according to yet unpublished investigations from the Balkan Green Belt - Osogovo project (Bulgarian Biodiversity Foundation). However we did not find any Alchemilla species in the Vaccinium heaths for this mountain. Their presence in the respective communities from West Balkan Mt. can be explained by the longer hold of the snow-cover in that region, which provides the necessary humidity for the Alchemilla species development. At the same time the height of the heath-berries is rather small $(30-40 \mathrm{~cm})$, which can be explained by the regular harvesting of fruit on a large scale.

From the six reported species of genus Alchemilla, only A. erythropoda does not possess proven medicinal properties. The distribution of the species in the particular phytocenoses and habitats is always mosaic, which is conditioned by the dissemination fortuity, the specific features of the reproduction in genus Alchemilla and by the competitive interrelations in the plant communities.

Generally, the ascertained abundance of the Alchemilla species for both mountains is very low. We used for its characterization the index project coverage of the species which for the different experimental plots varies from 1 to $25 \%$. Only in 3 localities and on the respective experimental plots from the two mountain regions together, does the project coverage of Alchemilla species vary from 15 to $25 \%$. For the territory of Osogovo Mt. these localities come under the habitat types (D 2.3I) Balkan quaking bogs and (E 4. 318) Oro-Moesian mat-grass swards (Table 4) and for West Balkan Mt. under the habitat (E 3.46) Continental humid meadows (Table 5).

For the territory of Osogovo Mt., with largest areas (0.9-1.6 da), the localities were situated higher on the mountain - 1665-1791 m a.s.l. - and they were also in largest abundance. At lower elevation (within the borders of $\mathrm{E} 2.33$ ) the localities occupy smaller areas. This pattern can be explained by the better light regime at higher elevation, where the plant communities often are opened, mosaic and consist of short herbaceous representatives throughout. All the localities found in Osogovo Mt. occupy the altitude range of 1459-1791 m a.s.l. The exposition has a prevailing south or east component or a combination of both. The inclination varies from $3^{\circ}$ to $15^{\circ}$. The humidity in the separate localities changes at small extent and determines the range of ecological conditions in the localities from hygrophilous (bogs) to mesophile and xeromesophile (grass communities).

The localities in West Balkan Mt. are situated from $1382 \mathrm{~m}$ a.s.l. to $1714 \mathrm{~m}$ a.s.l., and have expositions with dominant north component. Covering the largest area ( $5 \mathrm{da}$ ) appear to be the localities, found within the boundaries of F 2.2A2 between $1691 \mathrm{~m}$ a.s.l. and $1711 \mathrm{~m}$ a.s.l., but the Alchemilla species there are sparsely distributed. These communities present a complex of heath-berries with grasses. The smallest $(0.05-0.5 \mathrm{da})$ are the localities which are situated within the habitat types E 2.33 and E 3.46, distributed between 1382 and 1429 m a.s.l. The localities of the Alchemilla spp. for both mountains are scattered throughout the territory of the investigated regions, which it difficult to utilizef the resources.

\section{CONCLUSIONS}

Taking into consideration the limited investigation area for both mountains, the seven ascertained Alchemilla species show the presence of a comparatively large diversity within the genus for Osogovo Mt. and West Balkan Mt.

A. crinita, which is reported for the first time for the territory of Osogovo Mt. and West Balkan Mt. and appears in the majority of the plots, turns out to be most common species for both regions.

The specified Alchemilla species occur in sublevels of the following main habitat types: Transition mires and quaking bogs (D 2.3), Mountain hay meadows (E 2.3), Moist or wet eutrophic and mesotrophic grassland (E 3.4), Acid alpine and subalpine grassland (E 4.3), Subalpine moist or wet tall-herb and fern stands (E 5.5), Evergreen alpine and subalpine heath and scrub (F 2.2). These types of habitats and the related communities meet to a high degree the ecological requirements of the Alchemilla species as they provide good light regime, high humidity and well drained soil at the respective elevation. 
The low project coverage and relatively small sizes of the localities are conditions for the perceptibly low abundance of the Alchemilla species. That is why the resources of Alchemilla spp. in West Balkan Mt. and Osogovo Mt. are limited and can be harvested sustainably only for personal needs and under strict monitoring.

\section{REFERENCES}

Assenov, I. 1975: Genus Alchemilla L. In: Jordanov, D. (ed.): Flora of PR Bulgaria, vol. 5. BAS, Sofia, pp. 274-329.

Assyov, B. \& Petrova, A. (eds.) 2006: Conspectus of the Bulgarian Vascular Flora. Distribution Maps and Floristic Elements. ed. 3., BBF, Sofia, $453 \mathrm{pp}$.

Braun-Blanquet, J. 1964: Pflanzensoziologie Grundzüge der Vegetationskunde, Wien, $865 \mathrm{pp}$.

Delipavlov, D., Cheshmedzhiev, I., Popova, M., Terziyski, D. \& Kovachev, I. 2003: Handbook to the vascular plants in Bulgaria. Acad. Press of Agricult. Univ., Plovdiv, 591 pp. (in Bulgarian).

Fröhner, S.E. 1995. Alchemilla. In: Scholz, H., Conert, H.J., Jäger, E.J., Kadereit, J.W., SchultzeMotel, W., Wagenitz, G. Weber, H.E. (eds.), Hegi: Illustrierte Flora von Mitteleuropa, 4 Teil 2B. Verlag Paul Parey, Berlin, Germany, pp. 13-242.

Gehrke, B., Bräuchler, C., Romoleroux, K., Lundberg, M., Heubl, G., Eriksson, T. 2008: Molecular phylogenetics of Alchemilla, Aphanes and Lachemilla (Rosaceae) inferred from plastid and nuclear intron and spacer DNA sequences, with comments on generic classification. Molecular Phylogenetics and Evolution 47: 1030-1044.

Glazunova, K.P. 1987: Formation of the embryo sacks in agamous species of the lady's mantle (Alchemilla L.). Byull. MOIP, Otd. boil.: 92 (5): 96-110. (in Russian).

Izmailow, R. 1994: Further observation in embryo sacks development in Alchemilla L. (subsection Heliodrosium Rothm.). Acta Biol. Cracov., Ser. Botanica 36:37-41.

Jordanov, D. (ed.) 1963-1979: Flora of PR Bulgaria, Vol. 1-7. BAS, Sofia. (in Bulgarian).

Jordanova, M. 2002: Hydrological regioning. In: Kopralev, I. (ed.): Physical and socio-economic geography. ForKom, Sofia. pp. 242-246 (in Bulgarian).
Kozhuharov, St. (ed.) 1992: Field Guide to the Vascular Plants in Bulgaria. Nauka i izkustvo, Sofia, 788 pp. (in Bulgarian).

Kodzuharov, St. (ed.) 1995: Flora of R Bulgaria, Vol. 10. Academic Press "Prof. Marin Drinov", Sofia. (in Bulgarian).

Kurtto, A., Fröhner S.E. \& Lampinen, R. (eds.) 2007: Atlas Florae Europaeae. Distribution of Vascular Plants in Europe. 14. Rosaceae (Alchemilla and Aphanes). - The Committee for Mapping the Flora of Europe \& Societas Biologica Fennica Vanamo, Helsinki, pp. 23-169.

Lovelius, O. 1987: Genus Alchemilla L. (Rosaceae) in Flora Montium Carpates Ucrainici. In: Grubov, V.I. (ed.): Novitates Systematicae Plantarum Vascularium. Tomus 24. Nauka, Leningrad, pp. 107-115 (in Russian).

Medicinal Plants Act (2000). State Gazette, 29 / 07. 04. 2000 (in Bulgarian).

Ninov, N. 2002: Soil regioning. In: Kopralev, I. (ed.): Physical and socio-economic geography. ForKom, Sofia, pp. 300-312 (in Bulgarian).

Penchev, P. \& al. 1989: Balkan Mountain region. In: Mishev, K. (ed.): Geography of Bulgaria, vol. 3. BAS, Sofia, pp. 85-111 (in Bulgarian).

Sepp, S., Bobrova, V.K., Troitsky, A.K. \& Glazunova, K.P. 2000: Genetic polymorphism detected with RAPD analysis and morphological variability in some microspecies of apomictic Alchemilla. Ann. Bot. Fennici 37: 105-123.

Vapcarov, I. \& al. 1989: Rilo-Rhodopide region. In: Mishev, K. (ed.): Geography of Bulgaria, vol. 3. BAS, Sofia, pp. 166-220 (in Bulgarian).

Velchev, V. (ed.) 1982-1989: Flora of PR Bulgaria, vol. 8-9. BAS, Sofia. (in Bulgarian)

Velev, St. 2002: Climatic regioning. In: Kopralev, I. (ed.): Physical and socio-economic geography. ForKom, Sofia, pp. 155-157 (in Bulgarian).

Walters, S.M. \& Pawlowski, B. (Ser. Elatae) 1968: Alchemilla L. In: Tutuin, T.G. \& al. (ed.): Flora Europaea, Rosaceae to Umbelliferae, Cambridge University Press, Cambridge, 2: 48-68.

Zagorchev, I. 2008. Amphibolite-facies metamorphic complexes in Bulgaria and recambrian geodynamics: controversies and "state of the art”. In: Geologica Balcanica, 37. 1-2, Sofia, Iun. 2008, p. 34.

http://eunis.eea.europa.eu/habitats.jsp

Recieved 30. 10. 2009

Revision recieved 23. 2. 2010 Accepted 26. 2. 2010 
Table 1: Floristic composition of the investigated localities with presence of Alchemilla spp. and assessment of the species abundance according to Braun-Blanquet (1964).

Tabela 1: Floristična sestava na raziskovanih ploskvah s prisotnostjo vrst Alchemilla spp. in ocena pogostnosti po Braun-Blanquet-u (1964).

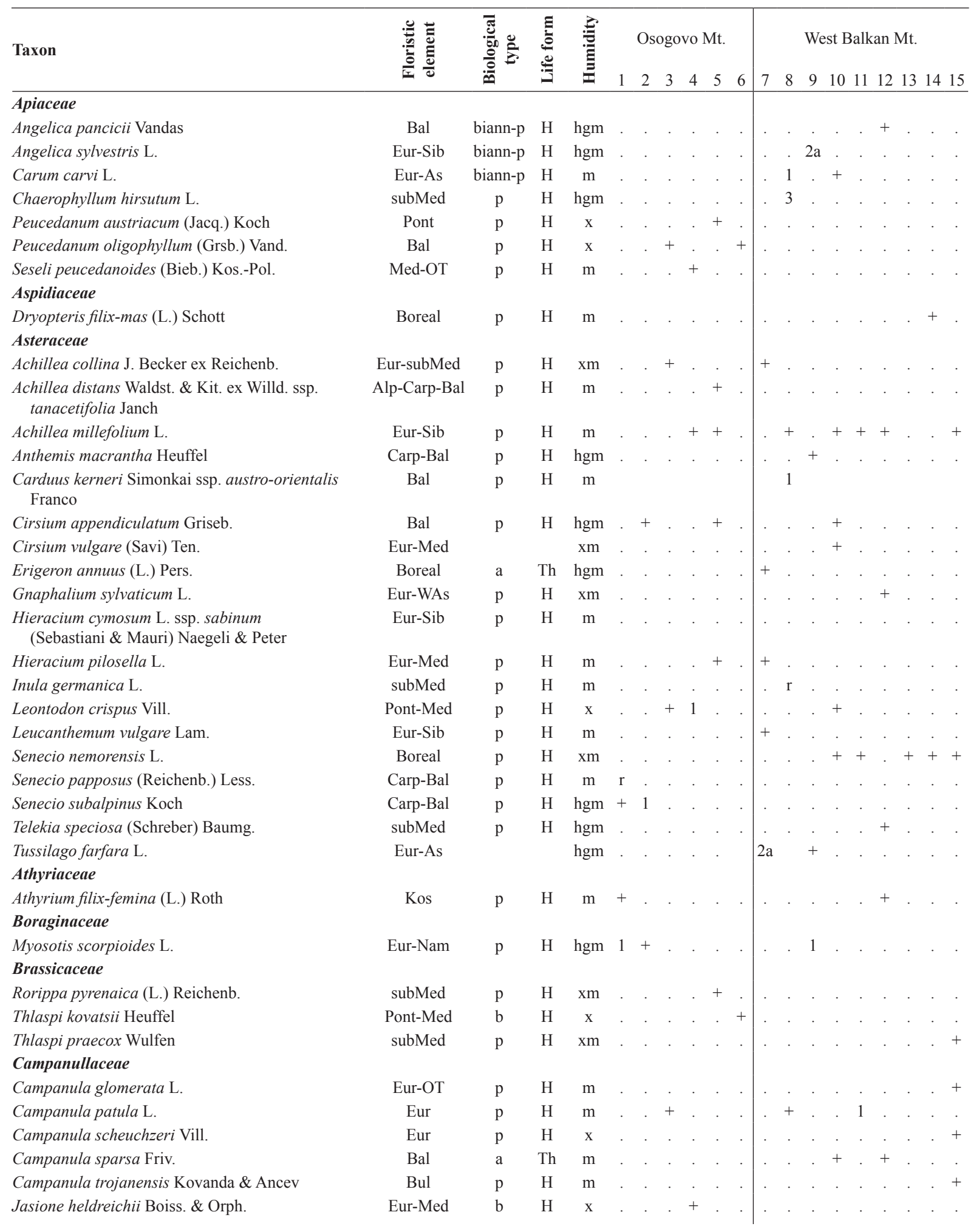




\begin{tabular}{|c|c|c|c|c|c|c|c|c|c|c|c|c|c|c|c|c|c|c|c|}
\hline \multirow{2}{*}{ Taxon } & \multirow{2}{*}{ 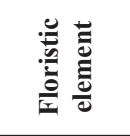 } & \multirow{2}{*}{ 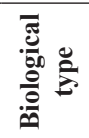 } & \multirow{2}{*}{$\begin{array}{l}\Xi \\
\stackrel{\Xi}{\Xi} \\
\stackrel{\Xi}{\Xi}\end{array}$} & \multirow{2}{*}{ 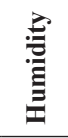 } & \multicolumn{6}{|c|}{ Osogovo Mt. } & \multicolumn{9}{|c|}{ West Balkan Mt. } \\
\hline & & & & & 1 & 2 & 3 & 4 & 5 & 6 & 7 & 8 & 9 & 10 & 11 & 121 & 131 & 141 & 15 \\
\hline \multicolumn{20}{|l|}{ Caryophyllaceae } \\
\hline Cerastium alpinum $\mathrm{L}$. & Arct-Alp & $\mathrm{p}$ & $\mathrm{H}$ & $\mathrm{x}$ & . & . & . & . & + & & & . & . & . & . & . & . & . & \\
\hline Cerastium petricola Pancic & Bal & ann-b & Th-H & $\mathrm{xm}$ & . & . & . & . & . & . & & . & . & . & . & . & . & . & + \\
\hline Dianthus armeria $\mathrm{L}$. & Eur & ann-b & Th-H & $\mathrm{m}$ & . & . & . & . & . & . & . & . & . & . & . & 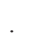 & . & . & + \\
\hline Dianthus giganteus D’Urv. & subMed & $\mathrm{p}$ & $\mathrm{H}$ & $\mathrm{xm}$ & . & . & . & + & . & . & . & . & . & . & . & . & . & . & . \\
\hline Silene otites (L.) Wibel & Eur-Med & $\mathrm{p}$ & $\mathrm{H}$ & $\mathrm{x}$ & . & . & + & . & . & . & . & . & . & . & . & 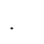 & . & . & . \\
\hline Silene vulgaris (Moench) Garcke & Eur-As & $\mathrm{a}$ & Th & $\mathrm{xm}$ & . & . & . & . & . & . & & + & . & . & . & . & . & . & + \\
\hline Stellaria graminea $\mathrm{L}$. & Eur-As & $\mathrm{p}$ & $\mathrm{H}$ & $\mathrm{m}$ & . & . & + & 1 & . & + & . & + & . & + & + & + & . + & +- & + \\
\hline $\begin{array}{l}\text { Viscaria vulgaris Rohling ssp. atropurpurea } \\
\text { (Griseb.) Stoj. }\end{array}$ & Eur-Sib & $\mathrm{p}$ & $\mathrm{H}$ & $\mathrm{xm}$ & . & . & + & . & . & . & . & . & . & . & . & . & . & . & . \\
\hline \multicolumn{20}{|l|}{ Cistaceae } \\
\hline Heliantheтит nuтmularium (L.) Miller & Alp-Med & $\mathrm{p}$ & $\mathrm{H}$ & $\mathrm{x}$ & . & . & . & 1 & . & ${ }^{\circ}$ & . & . & . & . & . & . & . & . & \\
\hline \multicolumn{20}{|l|}{ Cupressaceae } \\
\hline Juniperus sibirica Burgsd. & Boreal & sh & $\mathrm{Ch}$ & $\mathrm{x}$ & 1 & . & . & . & 1 & + & + & . & . & + & + & . & 12 & 2a 2 & $2 b$ \\
\hline \multicolumn{20}{|l|}{ Cyperaceae } \\
\hline Carex echinata Murray & Kos & $\mathrm{p}$ & $\mathrm{H}$ & hg & $2 \mathrm{a}$ & 1 & . & . & . & . & . & . & . & . & . & + & . & . & \\
\hline Carex hirta $\mathrm{L}$. & Boreal & $\mathrm{p}$ & $\mathrm{H}$ & mhg & . & . & . & . & . & . & . & . & $2 \mathrm{a}$ & . & . & . & . & . & \\
\hline Carex cinerea Poll. & Boreal & $\mathrm{p}$ & $\mathrm{H}$ & hg & . & . & . & . & . & . & . & . & $2 \mathrm{a}$ & . & . & . & . & . & \\
\hline Carex nigra (L.) Reichenb. & Alp-Carp & $\mathrm{p}$ & $\mathrm{H}$ & hg & 3 & 4 & . & . & . & . & . & . & . & . & . & . & . & . & . \\
\hline Carex pallescens $\mathrm{L}$. & Boreal & $\mathrm{p}$ & $\mathrm{H}$ & $\mathrm{m}$ & $2 b$ & . & . & . & . & . & . & . & . & . & . & + & . & . & \\
\hline Eriophorum angustifolium Honckeny & Boreal & $\mathrm{p}$ & $\mathrm{H}$ & hg & 1 & . & . & . & . & . & . & . & . & . & . & . & . & . & \\
\hline \multicolumn{20}{|l|}{ Dipsacaceae } \\
\hline Scabiosa columbaria $\mathrm{L}$. & Eur-Med & $\mathrm{p}$ & $\mathrm{H}$ & $\mathrm{m}$ & . & . & . & + & . & . & + & . & . & + & + & . & . + & + & \\
\hline Succisa pratensis Moench & Eur & $\mathrm{p}$ & $\mathrm{H}$ & hgm & . & . & . & . & . & . & . & . & + & . & . & . & . & . & \\
\hline \multicolumn{20}{|l|}{ Ericaceae } \\
\hline Bruckenthalia spiculifolia (Salisb.) Reichenb. & subMed & $\mathrm{sh}$ & $\mathrm{Ch}$ & $\mathrm{mx}$ & . & . & . & . & . & . & . & . & . & . & + & .2 & $2 \mathrm{a}$ & . 2 & $2 \mathrm{a}$ \\
\hline Vaccinium myrtillus L. & Boreal & $\mathrm{sh}$ & $\mathrm{Ch}$ & $\mathrm{mx}$ & + & . & . & . & + & . & . & . & . & 1 & + & +2 & $2 \mathrm{~b} 3$ & 32 & $2 \mathrm{~b}$ \\
\hline Vaccinium vitis-idaea $\mathrm{L}$. & Boreal & sh & $\mathrm{Ch}$ & $\mathrm{mx}$ & . & . & . & . & . & . & $\cdot$ & . & . & + & . & .2 & $2 \mathrm{a} 2$ & $2 \mathrm{~b} 2$ & $2 \mathrm{a}$ \\
\hline Euphorbiaceae & & & & & & & & & & & & & & & & & & & \\
\hline Euphorbia cyparissias L. & Eur & $\mathrm{p}$ & $\mathrm{H}$ & $\mathrm{x}$ & . & . & + & . & + & . & . & . & . & . & . & . & . & . & \\
\hline Fabaceae & & & & & . & . & . & . & . & . & . & . & . & . & . & . & . . & & \\
\hline $\begin{array}{l}\text { Chamaecytisus absinthioides (Janka) } \\
\text { Kuzmanov }\end{array}$ & Bal & $\mathrm{sh}$ & $\mathrm{Ch}$ & $\mathrm{mx}$ & . & . & . & . & 1 & + & . & . & . & . & . & . & 1. & . 2 & $2 \mathrm{a}$ \\
\hline Chamaespartium sagittale (L.) P. Gibbs & Eur & & & $\mathrm{m}$ & . & . & 1 & $2 \mathrm{a}$ & + & 1 & . & . & . & . & + & . & 1. & . & \\
\hline Genista depressa Bieb. & subMed & $\mathrm{sh}$ & $\mathrm{H}$ & $\mathrm{x}$ & . & . & . & . & . & + & . & . & . & . & . & . & + . & . & . \\
\hline Lathyrus pratensis $\mathrm{L}$. & subBoreal & $\mathrm{p}$ & $\mathrm{H}$ & $\mathrm{m}$ & 1 & + & . & . & . & . & . & . & + & . & . & . & . & . & . \\
\hline Lotus corniculatus $\mathrm{L}$. & Eur-Med & $\mathrm{p}$ & $\mathrm{H}$ & $\mathrm{xm}$ & . & . & + & . & . & . & . & . & . & + & . & . & . & . & . \\
\hline Lupinus albus L. & Med & $\mathrm{p}$ & $\mathrm{H}$ & $\mathrm{xm}$ & . & . & . & . & . & . & . & $\mathrm{r}$ & . & . & . & . & . & . & . \\
\hline Medicago falcata $\mathrm{L}$. & Eur-As & $\mathrm{p}$ & $\mathrm{H}$ & $\mathrm{mx}$ & . & . & . & . & . & . & $2 \mathrm{a}$ & . & . & . & . & . & . & . & . \\
\hline Medicago minima (L.) Bartal. & Eur-As & a & Th & $\mathrm{mx}$ & . & . & . & . & . & . & + & . & . & . & . & . & . & . & . \\
\hline Trifolium alpestre $\mathrm{L}$. & Eur-Sib & $\mathrm{p}$ & $\mathrm{H}$ & $\mathrm{mx}$ & . & . & . & + & + & . & + & . & . & + & . & . & . & . & . \\
\hline Trifolium dubium Sibth. & Eur-Med & a & Th & $\mathrm{mx}$ & . & . & . & . & . & . & 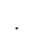 & . & + & . & . & . & . & . & . \\
\hline Trifolium patens Schreber & subMed & $\mathrm{a}$ & Th & $\mathrm{mx}$ & . & . & + & . & . & . & . & . & . & . & . & . & . & . & . \\
\hline Trifolium pratense $\mathrm{L}$. & subBoreal & $\mathrm{p}$ & $\mathrm{H}$ & $\mathrm{m}$ & . & . & + & + & + & & . & + & + & . & + & . & . & . & . \\
\hline Trifolium repens $\mathrm{L}$. & Eur-Sib & $\mathrm{p}$ & $\mathrm{H}$ & $\mathrm{m}$ & 1 & . & . & . & . & . & & + & . & . & . & . & . & . & \\
\hline Gentianaceae & & & & & & & & & & & & & & & & & & & \\
\hline Gentiana cruciata $\mathrm{L}$. & Eur-Sib & $\mathrm{p}$ & $\mathrm{H}$ & $\mathrm{mx}$ & . & . & . & . & . & . & & . & . & + & . & . & . + & +1 & 1 \\
\hline Geraniaceae & & & & & & & & & & & & & & & & & & & \\
\hline Geranium pyrenaicum Burm.f. & subMed & $\mathrm{p}$ & $\mathrm{H}$ & $\mathrm{xm}$ & . & . & . & . & . & 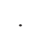 & & + & . & . & . & . & . . & . & \\
\hline Geranium sylvaticum L. & Boreal & $\mathrm{p}$ & $\mathrm{H}$ & $\mathrm{xm}$ & . & . & . & . & . & & & . & . & . & . & & . + & & + \\
\hline Hypericaceae & & & & & & & & & & & & & & & & & & & \\
\hline Hypericum maculatum Crantz & Boreal & $\mathrm{p}$ & $\mathrm{H}$ & $\mathrm{m}$ & + & + & $2 \mathrm{~b}$ & $2 \mathrm{a}$ & + & & + & . & + & 1 & 1 & 1 & ++ & +1 & 1 \\
\hline Hypericum perforatum $\mathrm{L}$. & Kos & $\mathrm{p}$ & $\mathrm{H}$ & $\mathrm{mx}$ & . & . & . & . & . & & & $2 \mathrm{a}$ & . & . & . & . & . . & . & \\
\hline
\end{tabular}




\begin{tabular}{|c|c|c|c|c|c|c|c|c|c|c|c|c|c|c|c|c|c|c|c|}
\hline \multirow{2}{*}{ Taxon } & \multirow{2}{*}{ 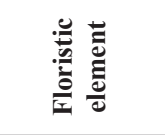 } & \multirow{2}{*}{ 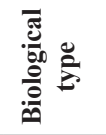 } & \multirow{2}{*}{$\underset{0}{0}$} & \multirow{2}{*}{ 总 } & \multicolumn{6}{|c|}{ Osogovo Mt. } & \multicolumn{9}{|c|}{ West Balkan Mt. } \\
\hline & & & & & 1 & 2 & 3 & 4 & 5 & 6 & 7 & 8 & 9 & 1011 & 111 & 21 & 31 & & 15 \\
\hline \multicolumn{20}{|l|}{ Juncaceae } \\
\hline Juncus atratus Krocker & subMed & $\mathrm{p}$ & $\mathrm{H}$ & hg & 1 & 1 & . & . & $\cdot$ & . & . & . & . & . . & . . & . & . & . & . \\
\hline Juncus conglomeratus L. & Eur & $\mathrm{p}$ & $\mathrm{H}$ & hg & . & + & . & . & . & . & . & . & . & . . & . . & . & . & . & . \\
\hline Juncus effusus L. & subBoreal & $\mathrm{p}$ & $\mathrm{H}$ & hg & $2 \mathrm{a}$ & 1 & . & . & . & . & . & . & . & . . & . 1 & 1 & . & . & . \\
\hline Juncus inflexus $\mathrm{L}$. & subBoreal & $\mathrm{p}$ & $\mathrm{H}$ & hg & . & . & . & . & . & . & . & . & 1 & . . & . . & . . & . & . & . \\
\hline Luzula campestris (L.) DC. & subBoreal & $\mathrm{p}$ & $\mathrm{H}$ & $\mathrm{x}$ & + & . & 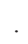 & + & & + & . & . & . & + . & . . & . . & . & . & . \\
\hline Luzula luzuloides (Lam.) Dandy \& Wilmott & Eur & $\mathrm{p}$ & $\mathrm{H}$ & $\mathrm{m}$ & + & . & . & + & 1 & . & . & . & . & $12 \mathrm{a}$ & $2 \mathrm{a}+$ & +1 & $1+$ & + & 1 \\
\hline \multicolumn{20}{|l|}{ Lamiaceae } \\
\hline Acinos alpinus (L.) Moench & Alp-Carp & $\mathrm{p}$ & $\mathrm{H}$ & $\mathrm{mx}$ & . & . & . & . & + & . & . & . & . & . . & . . & . & . & . & . \\
\hline Ajuga genevensis L. & sPont & $\mathrm{p}$ & $\mathrm{H}$ & $\mathrm{m}$ & . & . & . & . & + & . & + & . & . & . . & . . & . . & . & . & . \\
\hline Clinopodium vulgare L. & subBoreal & $\mathrm{p}$ & $\mathrm{H}$ & $\mathrm{x}$ & . & . & . & . & . & . & . & . & . & 1. & . . & . . & . & . & . \\
\hline Galeopsis tetrachit $\mathrm{L}$. & Eur-As & $\mathrm{a}$ & $\mathrm{Th}$ & $\mathrm{x}$ & . & . & . & . & . & . & . & . & . & . . & . + & + . & . & . & . \\
\hline Lamiastrum galeobdolon (L.) Ehrend. \& Polatschek & Med & $\mathrm{p}$ & $\mathrm{H}$ & $\mathrm{m}$ & . & . & . & . & + & . & . & . & . & . . & . . & .. & . & . & . \\
\hline Mentha arvensis $\mathrm{L}$. & Eur-As & $\mathrm{p}$ & $\mathrm{H}$ & $\mathrm{m}$ & . & . & . & . & + & . & . & . & . & . . & . . & . . & . & . & . \\
\hline Mentha longifolia (L.) Hudson & Eur-Sib & $\mathrm{p}$ & $\mathrm{H}$ & hgm & + & + & . & . & . & . & . & . & 3 & . . & . . & .. & . & . & . \\
\hline Mentha pulegium L. & Eur-As & $\mathrm{p}$ & $\mathrm{H}$ & hgm & . & . & . & . & + & . & . & . & . & . . & . . & . . & . & . & . \\
\hline Prunella laciniata (L.) L. & Eur & $\mathrm{p}$ & $\mathrm{H}$ & $\mathrm{m}$ & . & . & . & . & . & . & + & . & . & . . & . . & . . & . & . & . \\
\hline Prunella vulgaris L. & Kos & $\mathrm{p}$ & $\mathrm{H}$ & $\mathrm{xm}$ & + & . & . & . & . & . & . & . & . & . . & . + & + . & . & . & . \\
\hline Stachis sylvatica L. & Eur-As & $\mathrm{p}$ & $\mathrm{H}$ & $\mathrm{m}$ & . & . & . & . & . & . & . & + & . & . . & . . & . . & . & . & . \\
\hline Theucrium chamaedrys L. & subMed & $\mathrm{p}$ & $\mathrm{H}$ & $\mathrm{x}$ & . & . & . & . & . & . & + & . & . & . . & . . & . . & . & . & . \\
\hline Thymus sp. div. & & $\mathrm{p}$ & $\mathrm{H}$ & $\mathrm{mx}$ & . & . & . & . & + & 1 & . & . & . & . + & +1 & 11 & 1 & + & + \\
\hline \multicolumn{20}{|l|}{ Lentibulariaceae } \\
\hline Pinguicula balcanica Casper & Bal & $\mathrm{p}$ & $\mathrm{H}$ & mhg & + & + & . & . & . & . & . & . & . & . . & . . & & . & . & . \\
\hline \multicolumn{20}{|l|}{ Liliaceae } \\
\hline Allium carinatum $\mathrm{L}$. & Pont-Med & $\mathrm{p}$ & $\mathrm{Cr}$ & $\mathrm{mx}$ & . & . & + & + & . & . & . & . & . & . . & . . & . . & . & . & . \\
\hline Allium cirrhosum Vandelli & & $\mathrm{p}$ & $\mathrm{Cr}$ & $\mathrm{mx}$ & . & . & . & . & . & . & . & + & . & . . & . . & . . & . & . & . \\
\hline Ornithogalum nutans L. & Eur & $\mathrm{p}$ & $\mathrm{Cr}$ & $\mathrm{m}$ & . & . & . & . & + & . & . & . & . & . + & + . & . . & . & . & . \\
\hline $\begin{array}{l}\text { Veratrum album L. ssp. lobelianum (Bernh.) } \\
\text { Reichenb. }\end{array}$ & Eur-As & $\mathrm{p}$ & $\mathrm{Cr}$ & $\mathrm{m}$ & $2 \mathrm{a}$ & . & 1 & . & + & . & . & . & . & . . & . + & + & . & . & . \\
\hline \multicolumn{20}{|l|}{ Onagraceae } \\
\hline Chamaenerion angustifolium (L.) Scop. & subBoreal & $\mathrm{p}$ & $\mathrm{H}$ & $\mathrm{m}$ & . & . & . & . & . & . & + & . & . & . . & . + & + & . & . & . \\
\hline Epilobium collinum C.C.Gmelin & Eur-Med & $\mathrm{p}$ & $\mathrm{H}$ & $\mathrm{m}$ & . & . & . & . & . & . & . & . & + & . . & . . & . . & . & . & . \\
\hline Epilobium palustre $\mathrm{L}$. & subBoreal & $\mathrm{p}$ & $\mathrm{H}$ & hgm & . & + & . & . & . & . & . & . & . & . . & . . & . & . & . & . \\
\hline \multicolumn{20}{|l|}{ Ophioglossaceae } \\
\hline Botrychium lunaria (L.) Swartz & Boreal & $\mathrm{p}$ & $\mathrm{H}$ & $\mathrm{m}$ & . & . & . & . & . & + & . & . & . & . . & . . & . . & . & . & . \\
\hline Orchidaceae & & & & & & & & & & & & & & & & & & & \\
\hline Dactylorhiza cordigera (Fries) Soo & Carp-Bal & $\mathrm{p}$ & $\mathrm{Cr}$ & hgm & $2 \mathrm{a}$ & . & . & . & . & . & . & . & . & . . & . . & . & . & . & . \\
\hline Gymnadenia conopsea (L.) R.Br. & Eur-As & $\mathrm{p}$ & $\mathrm{Cr}$ & $\mathrm{m}$ & . & . & . & + & . & . & . & . & . & . . & . . & . . & . & . & . \\
\hline Parnassiaceae & & & & & & & & & & & & & & & & & & & \\
\hline Parnassia palustris $\mathrm{L}$. & subBoreal & $\mathrm{p}$ & $\mathrm{H}$ & mhg & + & + & . & . & . & . & . & . & + & . . & . & .. & . & . & . \\
\hline Pinaceae & & & & & & & & & & & & & & & & & & & \\
\hline Pinus sylvestris L. & subBoreal & shrub-t & $\mathrm{Ch}$ & $\mathrm{mx}$ & . & . & . & + & . & + & . & . & . & . . & . & . & . & . & . \\
\hline Plantaginaceae & & & & & & & & & & & & & & & & & & & \\
\hline Plantago subulata L. & Med & $\mathrm{p}$ & $\mathrm{H}$ & $\mathrm{x}$ & . & . & . & . & + & + & . & . & . & . & . & . & . & & . \\
\hline Plantago lanceolata $\mathrm{L}$. & Kos & $\mathrm{p}$ & $\mathrm{H}$ & $\mathrm{x}$ & . & . & . & . & . & . & + & + & . & . . & . & . & . & . & . \\
\hline Poaceae & & & & & & & & & & & & & & & & & & & \\
\hline Agrostis capillaris L. & Boreal & $\mathrm{p}$ & $\mathrm{H}$ & $\mathrm{xm}$ & . & + & 3 & . & . & + & $2 \mathrm{a}$ & $2 b$ & $2 \mathrm{a}$ & $2 b$. & 2 & b 2 & $2 a$ & & . \\
\hline Anthoxanthum odoratum $\mathrm{L}$. & Eur-As & $\mathrm{p}$ & $\mathrm{H}$ & $\mathrm{xm}$ & . & . & 1 & 1 & $2 \mathrm{a}$ & . & 1 & 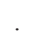 & . & & $2 \mathrm{a}+$ & +1 & 12 & $2 \mathrm{a}$ & + \\
\hline Arrhenatherum elatius (L.) Beauv. ex J.\&C.Presl & Eur-As & $\mathrm{p}$ & $\mathrm{H}$ & $\mathrm{xm}$ & . & . & . & . & $\cdot$ & . & $2 \mathrm{a}$ & . & . & . . & . . & . & . & . & . \\
\hline Bellardiochloa variegata (Lam.) Kerguelen & subMed-Anat & $\mathrm{p}$ & $\mathrm{H}$ & $\mathrm{m}$ & . & . & . & . & $2 b$ & . & . & . & . & + . & . . & . & . & . & . \\
\hline Briza media $\mathrm{L}$. & Eur & $\mathrm{p}$ & $\mathrm{H}$ & $\mathrm{m}$ & . & . & . & + & 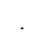 & . & $2 b$ & . & . & . . & . . & . & . & . & . \\
\hline Calamagrostis arundinacea (L.) Roth & subBoreal & $\mathrm{p}$ & $\mathrm{H}$ & $\mathrm{xm}$ & . & . & . & . & $\cdot$ & . & . & . & . & & 1. & . &. & 12 & $2 a$ \\
\hline
\end{tabular}




\begin{tabular}{|c|c|c|c|c|c|c|c|c|c|c|c|c|c|c|c|c|c|c|c|}
\hline \multirow{2}{*}{ Taxon } & \multirow{2}{*}{ 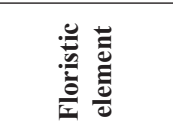 } & \multirow{2}{*}{ 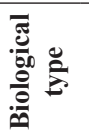 } & \multirow{2}{*}{ 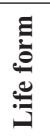 } & \multirow{2}{*}{ 胥 } & \multicolumn{6}{|c|}{ Osogovo Mt. } & \multicolumn{9}{|c|}{ West Balkan Mt. } \\
\hline & & & & & 1 & 2 & 3 & 4 & 5 & 6 & 7 & 8 & 9 & 10 & 11 & 12 & 13 & 14 & 15 \\
\hline Cynosurus cristatus $\mathrm{L}$. & Eur & $\mathrm{p}$ & $\mathrm{H}$ & $\mathrm{xm}$ & + & + & 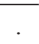 & . & . & . & . & . & 1 & . & . & + & . & . & . \\
\hline Cynosurus echinatus L. & subMed & $\mathrm{a}$ & $\mathrm{Th}$ & $\mathrm{mx}$ & . & + & . & . & . &. & . & . & . & . & . & . & . & . & \\
\hline Dactylis glomerata L. & Eur-As & $\mathrm{p}$ & $\mathrm{H}$ & $\mathrm{mx}$ & . & . & + & . & 1 & & $2 \mathrm{a}$ & $2 b$ & & . & . & . & . & . & r. \\
\hline Deschampsia caespitosa (L.) Beauv. & Boreal & $\mathrm{p}$ & $\mathrm{H}$ & $\mathrm{m}$ & 1 & 1 & . & . & . & . & . & . & $2 b$ & . & . & + & . & . & . \\
\hline Deschampsia flexuosa (L.) Trin. & Boreal & $\mathrm{p}$ & $\mathrm{H}$ & $\mathrm{m}$ & . & . & . & . & . & $2 \mathrm{~b}$ & . & . & . & . & $2 \mathrm{a}$ & + & 1 & $2 \mathrm{a}$ & $2 a$ \\
\hline Elymus repens (L.) Gould. & Boreal & $\mathrm{p}$ & $\mathrm{H}$ & $\mathrm{m}$ & . & . & . & . & . &. & . & . & $2 \mathrm{a}$ & . & . & . & . & . & . \\
\hline Festuca dalmatica (Hackel) K.Richter & subMed & $\mathrm{p}$ & $\mathrm{H}$ & $\mathrm{m}$ & . & . & $2 b$ & 3 & . & . & . & . & . & . & . & . & . & . & \\
\hline Festuca nigrescens Lam. & Eur & $\mathrm{p}$ & $\mathrm{H}$ & $\mathrm{m}$ & 1 & 1 & . & . & 3 & 3 & $\cdot$ & . & . & $2 b$ & + & . & + & $2 \mathrm{a}$ & + \\
\hline Festuca pratensis Hudson & Boreal & $\mathrm{p}$ & $\mathrm{H}$ & $\mathrm{m}$ & . & . & + & 3 & . & . & $2 \mathrm{a}$ & 1 & 1 & . & . & . & . & . & . \\
\hline Festuca rubra L. & Boreal & $\mathrm{p}$ & $\mathrm{H}$ & $\mathrm{m}$ & . & . & . & . & . & 3 & 1 & . & . & . & & 1 & . & . & \\
\hline Holcus mollis L. & Eur & $\mathrm{p}$ & $\mathrm{H}$ & $\mathrm{m}$ & . & . & . & . & . & 1 & . & . & . & . & . & . & . & . & . \\
\hline Molinia coerulea (L.) Moench & Boreal & $\mathrm{p}$ & $\mathrm{H}$ & hgm & 1 & + & . & . & . &. & . & . & . & . & $2 \mathrm{a}$ & 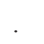 & . & . & . \\
\hline Nardus stricta L. & Arct-Alp & $\mathrm{p}$ & $\mathrm{H}$ & $\mathrm{mx}$ & . & . & . & $2 b$ & $2 \mathrm{a}$ & 3 & . & . & . & $2 \mathrm{a}$ & . & . & $2 \mathrm{a}$ & . & . \\
\hline Phleum alpinum $\mathrm{L}$. & Arct-Alp & $\mathrm{p}$ & $\mathrm{H}$ & $\mathrm{m}$ & . & . & . & . & . &. & . & . & 1 & . & . & . & . & . & . \\
\hline Phleum phleoides (L.) Karsten & Eur-As & $\mathrm{p}$ & $\mathrm{H}$ & $\mathrm{xm}$ & . & . & . & . & . &. & . & + & . & . & . & . & . & . & . \\
\hline Phleum pratense L. & Eur-subMed & $\mathrm{p}$ & $\mathrm{H}$ & $\mathrm{m}$ & . & . & . & . & . & . & 1 & . & + & . & . & . & . & . & . \\
\hline Poa pratensis $\mathrm{L}$. & Kos & $\mathrm{p}$ & $\mathrm{H}$ & $\mathrm{m}$ & . & . & + & . & . & . & . & 1 & . & 1 & . & . & + & . & . \\
\hline Sesleria comosa Velen. & Bal & $\mathrm{p}$ & $\mathrm{H}$ & $\mathrm{mx}$ & . & . & . & . & . &. & . & . & . & & $2 b$ & . & . & . & $\cdot$ \\
\hline Trisetum flavescens (L.) Beauv. & Boreal & $\mathrm{p}$ & $\mathrm{H}$ & $\mathrm{xm}$ & . & . & $2 b$ & . & . &. & . & 1 & . & . & . & . & . & . & . \\
\hline \multicolumn{20}{|l|}{ Polygonaceae } \\
\hline Bistorta major S.F.Gray & Eur-As & $\mathrm{p}$ & $\mathrm{H}$ & hgm & + & . & . & . & . &. & . & . & . & . & . & . & . & . & . \\
\hline Rumex acetosa L. & Boreal & $\mathrm{p}$ & $\mathrm{H}$ & $\mathrm{m}$ & . & . & . & . & . &. & . & 1 & . & . & & $2 \mathrm{a}$ & . & + & . \\
\hline Rumex acetosella L. & Eur-subMed & $\mathrm{p}$ & $\mathrm{H}$ & $\mathrm{mx}$ & . & . & . & + & . &. & . & . & . & . & . & . & . & . & 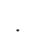 \\
\hline Rumex alpinus $\mathrm{L}$. & Alp-Carp-Bal & $\mathrm{p}$ & $\mathrm{H}$ & hgm & . & . & . & . & . & . & . & . & . & . & & 1 & . & . & . \\
\hline \multicolumn{20}{|l|}{ Primulaceae } \\
\hline Primula veris $\mathrm{L}$. & Eur-Med & $\mathrm{p}$ & $\mathrm{H}$ & $\mathrm{m}$ & . & . & . & 1 & . & . & + & . & . & . & . & . & . & . & . \\
\hline \multicolumn{20}{|l|}{ Ranunculaceae } \\
\hline Caltha palustris L. & Eur & $\mathrm{p}$ & $\mathrm{H}$ & hg & . & 1 & . & . & . & . & . & . & . & . & . & + & . & . & . \\
\hline Ranunculus acris L. & Kos & $\mathrm{p}$ & $\mathrm{H}$ & $\mathrm{m}$ & $2 b$ & + & . & . & + &. & . & 1 & . & + & + & + & + & . & . \\
\hline $\begin{array}{l}\text { Ranunculus bulbosus L. ssp. aleae (Willk.) } \\
\text { Rouy \& Fouc. }\end{array}$ & Eur & $\mathrm{p}$ & $\mathrm{H}$ & $\mathrm{mx}$ & . & . & . & . & . & + & . & . & . & . & . & . & . & . & . \\
\hline Ranunculus polyanthemos L. & Eur-subMed & $\mathrm{p}$ & $\mathrm{H}$ & $\mathrm{mx}$ & $2 b$ & . & . & . & . & . & . & . & . & . & . & . & . & . & . \\
\hline Ranunculus repens $\mathrm{L}$. & subMed & $\mathrm{p}$ & $\mathrm{H}$ & $\mathrm{m}$ & . & 1 & . & . & . & . & . & . & . & . & . & . & . & . & $\cdot$ \\
\hline Ranunculus serbicus Vis. & Ap-Bal & $\mathrm{p}$ & $\mathrm{H}$ & hgm & . & . & . & . & . &. & . & . & . & . & . & + & . & . & . \\
\hline \multicolumn{20}{|l|}{ Rosaceae } \\
\hline Agrimonia eupatoria L. & Eur-Med & $\mathrm{p}$ & $\mathrm{H}$ & $\mathrm{xm}$ & . & . & . & . & . & . & + & . & . & . & . & . & . & . & $\cdot$ \\
\hline Alchemilla crinita Buser & Eur & $\mathrm{p}$ & $\mathrm{Cr}$ & $\mathrm{m}$ & 1 & $2 \mathrm{a}$ & + & $2 \mathrm{a}$ & + & . & . & + & $2 b$ & . & . & 1 & . & . & . \\
\hline Alchemilla erythropodoides Pawl & & $\mathrm{p}$ & $\mathrm{Cr}$ & $\mathrm{m}$ & . & + & . & . & + & . & . & . & . & + & 1 & . & + & . & + \\
\hline Alchemilla flabellata Buser & Alp-Carp & $\mathrm{p}$ & $\mathrm{Cr}$ & $\mathrm{m}$ & . & . & . & . & . & $2 \mathrm{a}$ & . & . & . & . & . & . & . & . & + \\
\hline Alchemilla glabra Neygenf. & Eur-Sib & $\mathrm{p}$ & $\mathrm{Cr}$ & $\mathrm{m}$ & . & $2 \mathrm{a}$ & . & . & . &. & . & . & . & . & & 1 & . & + & + \\
\hline Alchemilla glaucescens Wallr. & Eur & $\mathrm{p}$ & $\mathrm{Cr}$ & $\mathrm{m}$ & 1 & . & . & . & . & . & + & . & . & . & + & . & + & . & + \\
\hline Alchemilla monticola Opiz & Eur-Sib & $\mathrm{p}$ & $\mathrm{Cr}$ & $\mathrm{m}$ & . & . & + & + & . & $2 \mathrm{a}$ & . & + & + & . & . & . & . & . & . \\
\hline Filipendula ulmaria (L.) Maxim. & subBoreal & $\mathrm{p}$ & $\mathrm{H}$ & hg & . & . & . & . & + & . & . & . & . & . & . & . & . & . & . \\
\hline Fragaria vesca $\mathrm{L}$. & subBoreal & $\mathrm{p}$ & $\mathrm{H}$ & $\mathrm{m}$ & . & . & . & . & + & . & 1 & . & . & + & & + & . & + & . \\
\hline Geum coccineum Sibth. \& Sm. & subMed & $\mathrm{p}$ & $\mathrm{H}$ & hgm & $2 \mathrm{a}$ & . & . & . & . &. & . & . & . & . & . & $2 \mathrm{a}$ & . & . & . \\
\hline Geum urbanum L. & subBoreal & $\mathrm{p}$ & $\mathrm{H}$ & $\mathrm{m}$ & . & . & . & . & . &. & . & + & . & . & . & . & . & . & . \\
\hline Potentilla erecta (L.) Rauschel & subBoreal & $\mathrm{p}$ & $\mathrm{H}$ & $\mathrm{m}$ & $2 \mathrm{a}$ & + & . & . & . & . & . & . & + & + & + & 1 & . & + & + \\
\hline Potentilla micrantha Ramond ex DC & Eur-subMed & $\mathrm{p}$ & $\mathrm{H}$ & $\mathrm{m}$ & . & . & . & . & . & + & . & . & . & . & . & . & . & . & $\cdot$ \\
\hline Potentilla ternata C.Koch & Carp-Bal & $\mathrm{p}$ & $\mathrm{H}$ & $\mathrm{m}$ & . & . & . & . & . &. & + & . & . & . & . & . & . & . & . \\
\hline Rosa canina $\mathrm{L}$. & subMed & $\operatorname{sh}$ & $\mathrm{Ph}$ & $\mathrm{x}$ & . & . & r. & . & . & . & . & . & . & + & . & . & . & . & . \\
\hline Rosa vosagiaca Desportes & subMed & sh & $\mathrm{Ph}$ & $\mathrm{x}$ & . & . & . & . & . & . & 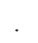 & . & . & . & . & . & . & + & $\cdot$ \\
\hline Rubus idaeus L. & subBoreal & sh & $\mathrm{Ph}$ & $\mathrm{mx}$ & . & . & r. & . & 1 & & . & 1 & + & . & + & + & . & . & + \\
\hline Sanguisorba officinalis L. & subBoreal & $\mathrm{p}$ & $\mathrm{H}$ & $\mathrm{m}$ & . & . & 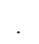 & . & . & . & + & . & 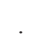 & . & . & . & . & . & \\
\hline
\end{tabular}




\begin{tabular}{|c|c|c|c|c|c|c|c|c|c|c|c|c|c|c|c|c|c|c|c|}
\hline \multirow{2}{*}{ Taxon } & \multirow{2}{*}{ 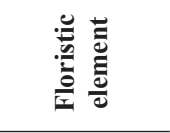 } & \multirow{2}{*}{ 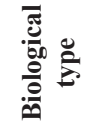 } & \multirow{2}{*}{ 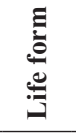 } & \multirow{2}{*}{ 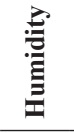 } & \multicolumn{6}{|c|}{ Osogovo Mt. } & \multicolumn{9}{|c|}{ West Balkan Mt. } \\
\hline & & & & & 1 & 2 & 3 & 4 & 5 & 6 & 7 & 8 & 9 & 10 & 11 & 12 & 13 & 14 & 15 \\
\hline \multicolumn{20}{|l|}{ Rubiaceae } \\
\hline $\begin{array}{l}\text { Asperula aristata L.f. ssp. longiflora (Waldst. \& } \\
\text { Kit.) Hayek }\end{array}$ & subMed & $\mathrm{p}$ & $\mathrm{H}$ & $\mathrm{xm}$ & . & . & . & . & . & + & . & . & . & . & . & . & . & . & . \\
\hline Asperula cynanchica $\mathrm{L}$. & Eur-Sib & $\mathrm{p}$ & $\mathrm{H}$ & $\mathrm{x}$ & . & . & . & + & . & . & . & . & . & $\cdot$ & . & . & . & . & . \\
\hline Cruciata glabra (L.) Ehrend. & sMed-CAs & $\mathrm{p}$ & $\mathrm{H}$ & $\mathrm{m}$ & . & . & . & + & . & + & + & . & . & + & + & . & + & 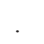 & + \\
\hline Cruciata laevipes Opiz & sMed-CAs & $\mathrm{p}$ & $\mathrm{H}$ & $\mathrm{m}$ & . & . & . & . & + & . & . & . & + & . & . & . & . & . & . \\
\hline Galium album Miller & Eur-As & $\mathrm{p}$ & $\mathrm{H}$ & $\mathrm{m}$ & . & + & . & . & + & . & . & . & . & + & . & . & . & . & + \\
\hline Galium aparine $\mathrm{L}$. & Eur-As & $\mathrm{p}$ & $\mathrm{H}$ & $\mathrm{xm}$ & . & . & . & . & . & . & . & . & + & . & . & . & . & . & . \\
\hline Galium uliginosum L. & Eur-As & $\mathrm{p}$ & $\mathrm{H}$ & hgm & + & . & . & . & . & . & . & . & + & . & . & . & . & . & . \\
\hline Galium verum $\mathrm{L}$. & Eur-As & $\mathrm{p}$ & $\mathrm{H}$ & $\mathrm{m}$ & . & . & + & $2 \mathrm{a}$ & . & . & $2 a$ & + & . & + & . & . & . & . & . \\
\hline \multicolumn{20}{|l|}{ Salicaceae } \\
\hline Salix caprea L. & subBoreal & shrub-t & $\mathrm{Ph}$ & hgm & . & . & . & . & . & . & . & . & . & . & . & + & . & . & . \\
\hline \multicolumn{20}{|l|}{ Scrophulariaceae } \\
\hline Euphrasia hirtella Jordan ex Reuter & Eur-As & $\mathrm{a}$ & Th & $\mathrm{m}$ & . & . & . & . & . & + & . & . & . & . & . & . & . & . & . \\
\hline Linaria dalmatica (L.) Miller & Med & $\mathrm{p}$ & $\mathrm{H}$ & $\mathrm{xm}$ & . & . & + & . & . & . & . & . & . & $\cdot$ & . & . & . & . & . \\
\hline Melampyrum sylvaticum L. & Eur & $\mathrm{a}$ & Th & $\mathrm{m}$ & . & . & . & . & . & . & . & . & . & . & . & . & . & + & . \\
\hline Rhinanthus alpinus Baumg. & Alp-Carp-Bal & a & Th & $\mathrm{m}$ & . & . & . & . & . & . & . & . & . & . & + & . & . & . & . \\
\hline Rhinanthus rumelicus Velen. & Eur-Med & a & Th & $\mathrm{mx}$ & . & . & . & + & . & . & + & . & . & . & . & . & . & . & . \\
\hline Scrophularia nodosa L. & subBoreal & $\mathrm{p}$ & $\mathrm{Cr}$ & $\mathrm{m}$ & . & . & . & . & . & . & . & + & . & . & . & . & . & . & . \\
\hline $\begin{array}{l}\text { Verbascum longifolium Ten ssp. pannosum } \\
\text { (Vis.) Murb. }\end{array}$ & Eur-Med & $\mathrm{b}$ & $\mathrm{H}$ & $\mathrm{mx}$ & . & . & + & . & + & . & . & . & . & + & . & + & + & + & + \\
\hline Veronica chamaedrys L. & Eur-As & $\mathrm{p}$ & $\mathrm{H}$ & $\mathrm{m}$ & . & . & . & + & + & . & . & . & . & + & + & + & . & + & + \\
\hline Veronica jaquinii Baumg. & & $\mathrm{p}$ & $\mathrm{H}$ & $\mathrm{xm}$ & . & . & . & . & . & . & + & . & . & . & . & . & . & . & . \\
\hline Veronica vindobonensis (M.Fischer) M.Fischer & Eur & $\mathrm{p}$ & $\mathrm{H}$ & $\mathrm{m}$ & . & . & . & . & . & . & . & + & + & . & . & . & . & . & . \\
\hline \multicolumn{20}{|l|}{ Thymelaeaceae } \\
\hline Daphne mezereum L. & Eur-Sib & sh & $\mathrm{Ph}$ & $\mathrm{m}$ & . & . & . & . & . & . & . & . & . & $\cdot$ & . & . & . & + & . \\
\hline \multicolumn{20}{|l|}{ Urticaceae } \\
\hline Urtica dioica $\mathrm{L}$. & Boreal & $\mathrm{p}$ & $\mathrm{H}$ & $\mathrm{m}$ & . & . & . & . & + & . & . & 1 & . & $\cdot$ & . & . & . & . & . \\
\hline \multicolumn{20}{|l|}{ Violaceae } \\
\hline Viola aetolica Boiss. \& Heldr. & Bal & ann-b & Th-H & $\mathrm{xm}$ & . & . & . & . & + & . & . & . & . & . & . & . & . & . & . \\
\hline Viola dacica Borbas & Pont-Med & $\mathrm{p}$ & $\mathrm{H}$ & $\mathrm{m}$ & . & $\cdot$ & . & . & . & . & . & . & . & . & + & . & . & . & + \\
\hline Viola tricolor $\mathrm{L}$. & Eur-As & a & Th & $\mathrm{m}$ & . & 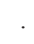 & . & . & . & . & . & . & . & + & + & + & + & + & . \\
\hline \multicolumn{20}{|l|}{ Sphagnaceae } \\
\hline Sphagnum spp. & & & & & + & + & . & . & $\cdot$ & & . & 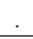 & . & . & . & + & . & . & . \\
\hline
\end{tabular}

Table 2: Habitat types with presence of Alchemilla spp. in Osogovo Mt.

Table 2: Habitatni tipi s prisotnostjo Alchemilla spp. na gorovju Osogovo.

\begin{tabular}{|c|c|c|c|c|}
\hline & GPS locations & Alchemilla spp. & EUNIS habitat type & Habitat diagnostic species from the descriptions \\
\hline 2 & $\begin{array}{l}\text { N } 4211.302 \\
\text { E } 2237.059 \\
\text { N } 4211.840 \\
\text { E } 2237.471\end{array}$ & $\begin{array}{l}\text { A. crinita, A. erythropodoides, } \\
\text { A. glabra, A. glaucescens }\end{array}$ & $\begin{array}{l}\text { D 2.3I Balkanic quaking } \\
\text { bogs }\end{array}$ & $\begin{array}{l}\text { Sphagnum spp., Pinguicula balcanica, Carex echinata, } \\
\text { Potentilla erecta, Eriophorum angustifolium, Parnassia } \\
\text { palustris }\end{array}$ \\
\hline 4 & $\begin{array}{l}\text { N } 4210.247 \\
\text { E } 2237.939 \\
\text { N } 4208.672 \\
\text { E } 2239.325\end{array}$ & A. crinita, A. monticola & $\begin{array}{l}\text { E } 2.33 \text { Balkan mountain } \\
\text { hay meadows }\end{array}$ & $\begin{array}{l}\text { Trisetum flavescens, Festuca pratensis, Rhinanthus } \\
\text { rumelicus }\end{array}$ \\
\hline 6 & $\begin{array}{l}\text { N } 4211.834 \\
\text { E } 2237.447 \\
\text { N } 4211.401 \\
\text { E } 2235.362\end{array}$ & $\begin{array}{l}\text { A. crinita, A. erythropodoides, } \\
\text { A. flabellata, A. monticola }\end{array}$ & $\begin{array}{l}\text { E } 4.318 \text { Oro-Moesian } \\
\text { mat-grass swards }\end{array}$ & $\begin{array}{l}\text { Festuca nigrescens, Festuca rubra, Anthoxantum } \\
\text { odoratum, Nardus stricta }\end{array}$ \\
\hline
\end{tabular}


Table 3: Habitat types with presence of Alchemilla spp. in West Balkan Mt.

Tabela 3: Habitatni tipi s prisotnostjo Alchemilla spp. na gorovju Stara Planina.

\begin{tabular}{|c|c|c|c|c|}
\hline & GPS locations & Alchemilla spp. & EUNIS habitat type & Habitat diagnostic species from the descriptions \\
\hline 2 & $\begin{array}{l}\text { N } 4306.335 \\
\text { E } 2307.354 \\
\text { N } 4307.024 \\
\text { E } 2307.567\end{array}$ & $\begin{array}{l}\text { A. crinita, A. glaucescens, } \\
\text { A. monticola }\end{array}$ & $\begin{array}{l}\text { E } 2.33 \text { Balkan mountain } \\
\text { hay meadows }\end{array}$ & $\begin{array}{l}\text { Festuca pratensis, Trisetum flavescens, Rhinanthus } \\
\text { rumelicus }\end{array}$ \\
\hline 3 & $\begin{array}{l}\text { N } 4306.373 \\
\text { E } 2308.808\end{array}$ & A. crinita, A. monticola & $\begin{array}{l}\text { E } 3.46 \text { Continental } \\
\text { humid meadows }\end{array}$ & $\begin{array}{l}\text { Festuca pratensis, Mentha longifolia, Deschampsia } \\
\text { caespitosa, Juncus inflexus }\end{array}$ \\
\hline 4 & $\begin{array}{l}\text { N } 4308.913 \\
\text { E } 2311.830\end{array}$ & A. erythropodoides & $\begin{array}{l}\text { E } 4.318 \text { Oro-Moesian } \\
\text { mat-grass swards }\end{array}$ & $\begin{array}{l}\text { Anthoxanthum odoratum, Nardus stricta, Festuca } \\
\text { nigrescens, Bellardiochloa violacea }\end{array}$ \\
\hline 5 & $\begin{array}{l}\text { N } 4308.391 \\
\text { E } 2311.541\end{array}$ & $\begin{array}{l}\text { A. erythropodoides, } \\
\text { A. glabra, } \\
\text { A. glaucescens }\end{array}$ & $\begin{array}{l}\text { E } 4.3944 \text { Oro-Moesian } \\
\text { [Sesleria comosa }] \\
\text { grasslands }\end{array}$ & Sesleria comosa \\
\hline 6 & $\begin{array}{l}\text { N } 4307.059 \\
\text { E } 2307.725\end{array}$ & A. crinita, A. glabra & $\begin{array}{l}\text { E } 5.572 \text { Moesian } \\
\text { scarlet avens tall herb } \\
\text { communities }\end{array}$ & Geum coccineum, Alchemilla spp. \\
\hline 7 & $\begin{array}{l}\text { N } 4308.164 \\
\text { E } 2311.540\end{array}$ & & & \\
\hline 8 & $\begin{array}{l}\text { N } 4308.251 \\
\text { E } 2311.523\end{array}$ & $\begin{array}{l}\text { A. erythropodoides, } \\
\text { A. flabellata, A. glabra, } \\
\text { A. glaucescens }\end{array}$ & $\begin{array}{l}\text { F 2.2A2 Balkano-Hellenic } \\
\text { dwarf bilberry heaths }\end{array}$ & Vaccinium myrthilus, Vaccinium vitis-idaea \\
\hline 9 & $\begin{array}{l}\text { N } 4308.339 \\
\text { E } 2311.506\end{array}$ & & & \\
\hline
\end{tabular}

Table 4: Habitat types with presence of Alchemilla spp. and characteristics of the localities in Osogovo Mt.

Tabela 4: Habitatni tipi s prisotnostjo Alchemilla spp. in značilnosti rastǐ̌č na gorovju Osogovo.

\begin{tabular}{|c|c|c|c|c|c|c|c|c|}
\hline & $\begin{array}{l}\text { GPS } \\
\text { locations }\end{array}$ & EUNIS habitat type & $\begin{array}{l}\text { Locality } \\
\text { area }\end{array}$ & $\begin{array}{l}\text { Project } \\
\text { coverage }\end{array}$ & Exposition & Slope & Humidity & Altitude \\
\hline 1 & $\begin{array}{l}\text { N } 4211.302 \\
\text { E } 2237.059\end{array}$ & \multirow{2}{*}{$\begin{array}{l}\text { D 2.3I Balkanic quaking } \\
\text { bogs }\end{array}$} & $0.9 \mathrm{dka}$ & $7 \%$ & south-west & $5^{\circ}$ & meso-hygrophile, hygrophile & $1665 \mathrm{~m}$ \\
\hline 2 & $\begin{array}{l}\text { N } 4211.840 \\
\text { E } 2237.471\end{array}$ & & $0.2 \mathrm{dka}$ & $15 \%$ & south & $15^{\circ}$ & meso-hygrophile, hygrophile & $1669 \mathrm{~m}$ \\
\hline 3 & $\begin{array}{l}\text { N } 4210.247 \\
\text { E } 2237.939\end{array}$ & \multirow{2}{*}{$\begin{array}{l}\text { E } 2.33 \text { Balkan mountain } \\
\text { hay meadows }\end{array}$} & $0.1 \mathrm{dka}$ & $2 \%$ & east & $10^{\circ}$ & mesophile & $1564 \mathrm{~m}$ \\
\hline 4 & $\begin{array}{l}\text { N } 4208.672 \\
\text { E } 2239.325\end{array}$ & & $0.1 \mathrm{dka}$ & $10 \%$ & east & $5^{\circ}$ & mesophile & $1459 \mathrm{~m}$ \\
\hline 5 & $\begin{array}{l}\text { N } 4211.834 \\
\text { E } 2237.447\end{array}$ & \multirow{2}{*}{$\begin{array}{l}\text { E } 4.318 \text { Oro-Moesian } \\
\text { mat-grass swards }\end{array}$} & $0.05 \mathrm{dka}$ & $2 \%$ & souht-east & $15^{\circ}$ & mesophile, xero-mesophile & $1565 \mathrm{~m}$ \\
\hline 6 & $\begin{array}{l}\text { N } 4211.401 \\
\text { E } 2235.362\end{array}$ & & $1.6 \mathrm{dka}$ & $15 \%$ & south-east & $3^{\circ}$ & mesophile, xero-mesophile & $1791 \mathrm{~m}$ \\
\hline
\end{tabular}


Table 5: Habitat types with presence of Alchemilla spp. and characteristics of the localities in West Balkan Mt. Tabela 5: Habitatni tipi s prisotnostjo Alchemilla spp. in značilnosti rastišč na gorovju Stara Planina.

\begin{tabular}{|c|c|c|c|c|c|c|c|c|}
\hline & $\begin{array}{l}\text { GPS } \\
\text { locations }\end{array}$ & EUNIS habitat type & $\begin{array}{l}\text { Locality } \\
\text { area }\end{array}$ & $\begin{array}{l}\text { Project } \\
\text { coverage }\end{array}$ & Exposition & Slope & Humidity & Altitude \\
\hline 1 & $\begin{array}{l}\text { N } 4306.335 \\
\text { E } 2307.354\end{array}$ & $\begin{array}{l}\text { E } 2.33 \text { Balkan } \\
\text { mountain hay }\end{array}$ & $0.05 \mathrm{dka}$ & $1 \%$ & south-west & $3^{\circ}$ & xero-mesophile, mesophile & $1415 \mathrm{~m}$ \\
\hline 2 & $\begin{array}{l}\text { N } 4307.024 \\
\text { E } 2307.567\end{array}$ & meadows & $0.1 \mathrm{dka}$ & $2 \%$ & north & $5^{\circ}$ & xero-mesophile, mesophile & $1429 \mathrm{~m}$ \\
\hline 3 & $\begin{array}{l}\text { N } 4306.373 \\
\text { E } 2308.808\end{array}$ & $\begin{array}{l}\text { E } 3.46 \text { Continental } \\
\text { humid meadows }\end{array}$ & $0.5 \mathrm{dka}$ & $25 \%$ & - & - & hygro-mesophile & $1382 \mathrm{~m}$ \\
\hline 4 & $\begin{array}{l}\text { N } 4308.913 \\
\text { E } 2311.830\end{array}$ & $\begin{array}{l}\text { E } 4.318 \text { Oro-Moesian } \\
\text { mat-grass swards }\end{array}$ & $1,5 \mathrm{dka}$ & $1 \%$ & north-east & $5^{\circ}$ & xero-mesophile, mesophile & $1467 \mathrm{~m}$ \\
\hline 5 & $\begin{array}{l}\text { N } 4308.391 \\
\text { E } 2311.541\end{array}$ & $\begin{array}{l}\text { E } 4.3944 \text { Oro-Moesian } \\
{[\text { Sesleria comosa }] \text { grasslands }}\end{array}$ & $2.0 \mathrm{dka}$ & $7 \%$ & north & $5^{\circ}$ & xero-mesophile, mesophile & $1714 \mathrm{~m}$ \\
\hline 6 & $\begin{array}{l}\text { N } 4307.059 \\
\text { E } 2307.725\end{array}$ & $\begin{array}{l}\text { E } 5.5724 \text { Moesian scarlet } \\
\text { avens tall herb communities }\end{array}$ & $1.0 \mathrm{dka}$ & $10 \%$ & north & $5^{\circ}$ & hygro-mesophile, mesophile & $1418 \mathrm{~m}$ \\
\hline 7 & $\begin{array}{l}\text { N } 4308.164 \\
\text { E } 2311.540\end{array}$ & & $5.0 \mathrm{dka}$ & $2 \%$ & north-east & $5^{\circ}$ & mesophile, xero-mesophile & $1691 \mathrm{~m}$ \\
\hline 8 & $\begin{array}{l}\text { N } 4308.251 \\
\text { E } 2311.523\end{array}$ & $\begin{array}{l}\text { F 2.2A2 Balkano-Hellenic } \\
\text { dwarf bilberry heaths }\end{array}$ & $0,5 \mathrm{dka}$ & $1 \%$ & south-west & $30^{\circ}$ & mesophile & $1704 \mathrm{~m}$ \\
\hline 9 & $\begin{array}{l}\text { N } 4308.339 \\
\text { E } 2311.506\end{array}$ & & $5.0 \mathrm{dka}$ & $4 \%$ & north & $30^{\circ}$ & mesophile & $1711 \mathrm{~m}$ \\
\hline
\end{tabular}

